\title{
Multiple Aspects of the Minority Language Issues of Eurasia
}

Heiko F. Marten, Michael RiessLER, JANNE SAARIKIVI \& ReEtTA ToIvanen (eds): Cultural and Linguistic Minorities in the Russian Federation and the European Union. Comparative Studies on Equality and Diversity. Multilingual Education, Volume 13. Springer. Cham, Heidelberg, New York, Dordrecht \& London, 2015.

\section{Cultural and Linguistic Minori-} ties in the Russian Federation and the European Union. Comparative Studies on Equality and Diversity is a book consisting of 12 chapters $^{1}$ and divided into three parts (Part I Languages, Identities and Human Rights; Part II Case Studies on Cultural Change and Minority Language Maintenance; Part III Why Some Languages Survive. On Language Laws, Policies and Changing Attitudes). The book also includes a preface written by the editors. Some of the chapters cover more than one language, and therefore the book deals with altogether 20 different languages. About half of the minority languages in question are spoken in the Russian Federation, and the other half in the European Union $^{2}$ (see Fig. 1 after the preface ${ }^{3}$ ).
The background of the book lies in Poga - The Language Survival Network, an informal interdisciplinary research network founded in 2007 (see p. ix and http://saami.unifreiburg.de/poga/). The authors of the chapters seem to have familiarized themselves with the issues of minority languages, in the event that this kind of expertise can be determined by mostly impressively long lists of references (see e.g. pp. 226-230).

Since the Poga Network is formed by scholars interested in the same kinds of questions without any restraints or more specific shared research interests or fields, the book at hand is a somewhat random collection of texts about the same subjects; random both in terms of the languages and the specific questions the book deals with. This kind of approach is fruitful, since it gives the reader a wide perspective on the issues of minority languages, covering different fields, from purely linguistic issues to legal and parliamentary questions. The selection of languages is presumably not very tightly controlled by the editors. Of course, there could have been a completely different selection of minority languages of the 
European Union and the Russian Federation with their own unique situations. Since not all the minority languages of the area can be dealt with in a single book, this selection is probably as good as any other.

The aim of the book according to the Preface (p. vii) is to publish material on the minority language issues of the Russian Federation in English in order to reach an audience who thus far has not had good access to the topic. There have been publications on similar issues in several languages (Zamyatin et al. 2012, and Sulkala \& Mantila, 2010, just to mention a couple), but the approaches in the books mentioned are different.

Even though the aim is to focus on the linguistic and cultural minorities of Russia, it is important to include some of the linguistic minorities of the European Union in the book. This reminds the English speaking audience, supposedly from the western world, that the situations of the minority languages are complex also within the European Union. The minority language situations are usually rather problematic, and each linguistic and cultural minority faces its own issues depending on policies and legislation, geography and history. That said, they also face somewhat similar situations, whether the language in question is Basque in
Spain (pp. 315-334), Inari Sami in Finland (pp. 98-101) or Nivkh on Sakhalin Island (pp. 233-252).

The book at hand, and especially the chapter Finnic Minorities in Ingria. The Current Sociolinguistic Situation and Its Background by Natalia Guznetsova, Elena Markus and Mehmet Muslimov (pp. 127167) brings out a common problem of academic publishing: the time from the actual study and fieldwork to the time of publishing is so long that the results may somewhat lose their value. The chapter is based on an impressive fieldwork project conducted in Ingria, where the scholars quite literary travelled from one village to another to count the speakers of different Finnic minority languages in the area. The fieldwork was carried out in 2006, and even back then the average age of the speakers for some of the languages was around 8o (for Votic see p. 137, for Ingrian p. 141). The results of the fieldwork are without a doubt very important information along with the introduction on the Finnic languages in Ingria. However, concerning the demographic situation of the speakers in question, the numeric data from 2006 is very out of date by the time the book has come out.

Part II of the book is precisely as stated in the title: Case Studies on Cultural Change and Minority Language Maintenance. Case 
studies, each providing a glimpse into a specific issue of one or more languages. Two chapters of this part deal with the issues of literary language. These are The Challenge of Language. On Developing Aboriginal Culture in Northern Russia by Lennard Sillanpää (pp. 169187), and Uneven Steps to Literacy. The History of the Dolgan, Forest Enents and Kola Sámi Literary Languages by Florian Siegl and Michael Rießler (pp. 189-230). While both of these chapters have their merits, they would have worked better if they had been presented in different order. The chapter by Siegl and Rießler is so thorough that it is the one to read when one is interested in the general issues of creating written languages for the different minority languages of Russia (and the Soviet Union). This chapter also answers the questions raised in the chapter by Sillanpää. Sillanpää's article also has its merits, but for a reader unaware of the issues of written languages in Russia, it would be easier to read after first having read the chapter by Siegl and Rießler. The picture is completed by Konstantin Zamyatin's chapter The Evolution of Language Ideology in Post-Soviet Russia (pp. 279-313).

More of an editorial and layout issue in the book at hand is the fact that many of the illustrations in the book do not work in the best pos- sible way. The maps in the different articles are blow-ups, which do not really give the reader any new information (see p. 109 and 234). The map in Fig. 1 (see footnote 3 ) is rather small, since it has to fit onto one page, but the language specific closeups are not helpful at all (with the exception of the map of Spain and the Basque-speaking areas on p. 317).

The same goes for some other illustrations. For instance, Table 1 on p. 248 is quite difficult to interpret, since the explanations are on the previous page. However, the tables (Table 1. p. 259 and Table 2. pp. 272-274) in the chapter Parliamentary Structures and Their Impact on Empowering Minority Language Communities by Heiko F. Marten (pp. 253-277) summarize the topic of the chapter very clearly. This is especially beneficial to a reader who is not very familiar with the political issues and parliamentary structures.

For someone still questioning why minority language and cultural issues are so important, and why this book was worth publishing, the answer can be found in the title of the chapter by Theodore S. Orlin (pp. 47-79): The Death of Languages; the Death of Minority Cultures; the Death of a People's Dignity. Its Implications for Democracy and the Commitment to Human Rights.

Elina Ahola 
Notes

1. The chapters themselves are not numbered. Numbering would make it easier to refer to them.

2. Some Sami languages are spoken both in the European Union (and Norway) and in the Russian Federation.

3. The page of the map is unfortunately not numbered. Counting from the last numbered page of the preface, it would be p. xix. The numbering of the wide array of illustrations is also separate for all the chapters.

\section{References}

Sulkala, Helena \& Mantila, Harri (ed.) 2010: Planning a new standard language. Finnic minority languages meet the new millenium. Studia Fennica Linguistica 15. Suomalaisen Kirjallisuuden Seura. Helsinki.

ZAMYATIN ET AL. 2012 = Константин Замятин, Анника Пасанен, Янне Саарикиви: Как и зачем сохранять языкии народов России? Авторы. Хельсинки. Available online: $<$ http://blogs.helsinki.fi/minor-eurus/ files/2012/12/kakizachem1.pdf>, $<$ http://saami.uni-freiburg.de/poga/>. Referred to on 10 Sep 2016. 